\title{
Russell Hamilton: Pioneering Critic of African Literatures in Portuguese
}

\author{
FERNANDO ARENAS \\ University of Michigan \\ ANA PAULA FERREIRA \\ University of Minnesota-Twin Cities
}

Russell Hamilton's scholarly career coincided with the anti-colonial liberation movements throughout the Portuguese African territories of Angola, Mozambique, Guinea-Bissau, Cape Verde, and São Tomé and Principe, in the 1960s and 70s. During this critical time-period, written literature in the form of poetry, short stories, essays, and novels played a major role among African elites by imagining these newly emerging nations. While denouncing the injustices and ravages of Portuguese colonialism, literary art galvanized readers to the cause of independence.

Hamilton was one of the pioneers of the systematic study of the literary production written in Portuguese from these new nations. His work was not only important in scholarly terms, but also historically, culturally, and politically. $\mathrm{He}$ combined socio-linguistic and socio-historical approaches with textual analysis, a methodology that he also implemented in his teaching.

Even though his primary objects of study were books, he felt strongly that in order to understand better the societies he studied, it was also imperative to experience them first-hand. Hamilton, his wife Cherie, and at various junctures, their children, thus traveled to Lusophone (or Portuguese-speaking) Africa, as well as to Brazil and Portugal. His commitment to bringing together book-based knowledge with experiential knowledge is an important part of his legacy to us all. Throughout his career, Hamilton built a wide and deep network of friendships 
and acquaintances with Lusophone African writers and intellectuals: Mário António, Manuel Ferreira, and Orlanda Amarílis in Lisbon; Arnaldo Santos, Boaventura Cardoso, Mário Pinto de Andrade, and José Luandino Vieira in Luanda; Luís Bernardo Honwana, José Craveirinha, Eugénio Lisboa, and Rui Knopfli in Lourenço Marques, among others.

In 1964, Hamilton joined the faculty of the University of Minnesota, where he spent the next twenty years. He is one of the founding members of the Department of Spanish and Portuguese, since previously it had been a Department of Romance Languages. After publishing several articles on Brazilian subjects, including Afro-Bahian cultural expression, and such authors as Jorge Amado and Graciliano Ramos, he began to cultivate an interest in Lusophone African literatures. In 1970-71, during a sabbatical year in Lisbon, he carried out research for a book on the literature of the five then-Portuguese colonies in Africa. It was also during that year that he made the first of his many trips to Africa. With the help of a Gulbenkian Foundation grant, he visited Angola, Cape Verde, and Mozambique in 1971, carrying out research for Voices from an Empire: A History of Afro-Portuguese Literature (1975). ${ }^{1}$ A grant from the Social Science Research Council allowed him to spend his 1978-79 sabbatical in four of the five by-then independent countries of Lusophone Africa, where he conducted research for Literatura Africana, Literatura Necessária, a two-volume study published in Lisbon in 1981 (vol. 1) and 1984 (vol. 2).

In 1984, Hamilton went to Vanderbilt University as Dean of the Graduate School. He was the first African-American Dean at this prestigious Southern liberal arts university. Throughout the sixteen years he served as Dean, he was able to teach an occasional course and maintain a research agenda until he retired in 2004. He was also instrumental in bringing African graduate students to the United States under the auspices of USAID, AFGRAD, and ATLAS programs. In fact, Hamilton traveled with Cherie to 23 different African countries to recruit graduate students. $95 \%$ of them returned to their countries of origin after completing their graduate studies. During Hamilton's time as dean of the Graduate School at Vanderbilt University, the number of ethnic minority graduate students, particularly African-Americans, increased quite significantly.

\footnotetext{
${ }^{1}$ Hamilton's wife, Cherie, has stated that the Portuguese government at the time did not allow them to travel to Guinea-Bissau.
} 
After Hamilton's return to Minneapolis, which he and Cherie considered "home," he contributed again to the Department of Spanish and Portuguese Studies at Minnesota by teaching an occasional course and giving lectures to graduate and undergraduate students. In 2007, he was one of the academics recognized with the Medalha do Vulcão by President Pedro Pires of Cape Verde. In that period, he was planning to revise and update Literatura Africana, Literatura Necessária and to write an autobiography about his social, intellectual, and cultural experiences in Brazil, Portugal, Angola, Cape Verde, Guinea-Bissau, Mozambique, and São Tomé e Príncipe.

In Voices from an Empire, Hamilton concludes optimistically that "[i]t can safely be said that Afro-Portuguese literature offers enough quantity, quality and regional diversity to be considered as several literatures" (397). Researched and written before the independence of the Portuguese African colonies, the book was published in 1975, before the publication of the bulk of Lusophone African literatures, which has occurred especially since the 1990s. It was also before the term "Lusophone" was used to refer to such literatures. It was not until 1996 that the heads of state of the Portuguese-speaking countries agreed officially to safeguard Portuguese against the encroachment of English and French. This was the event that crystallized the controversial concept of "Lusofonia," but in an article published in 1991 in Hispania, "Lusofonia, Africa, and Matters of Languages and Letters," Hamilton had already used the term to refer to the literatures of the independent African countries of official Portuguese expression. Portuguese had been imposed by the colonizers to oppress and govern but, ultimately, it was arguably the most important instrument to mobilize the anticolonial struggle and dream the independent African nations, as was argued by both Amílcar Cabral and José Luandino Vieira.

Literature in Lusophone Africa, as elsewhere throughout the continent, continues to enjoy significant prestige partly due to its venerable history during the crucial years of Pan-Africanism and Negritude during the first half of the twentieth century, as well as during the post-Second World War years with the consolidation of a national consciousness that became explicitly anti-colonial. In fact, as is well known, writers were among the founding mothers and fathers of numerous African nations. Hamilton's primary contribution to the field of Lusophone African literary studies, through Voices of an Empire and Literatura Africana, Literatura Necessária, was to map out systematically the literary fields 
of Angola, Cape Verde, Mozambique, São Tomé \& Principe, and Guinea-Bissau from the earliest texts written during the height of Portuguese colonialism in Africa to the textual production arising during the euphoric post-independence years. As argued by Hamilton, as well as critics of the field across the board, literature played a pivotal role in imagining the nation long before the rise of the liberation movements. Since independence, literature in Africa has remained a bastion of critical consciousness in the face of persistent socio-economic inequalities and unmet political expectations.

The first volume of Literatura Africana, Literatura Necessária is entirely dedicated to the history of Angolan literature, from its beginnings at the turn of the twentieth-century until the first years following independence in November 1975. While the first five chapters of the volume translate, expand upon and in certain instances refocus the material published in Voices from an Empire, most of chapter six through chapter nine discuss the main tendencies and literary works that surfaced in the years immediately before and after independence. The Portuguese military coup of April 25, 1974 is referenced repeatedly in these chapters as the main dividing line between a literature written under the oppressive structures of colonialism and what came after. Hamilton's main concern is with ascertaining the whereabouts of what he famously called the "acculturated literature" (Literatura Africana 1:22; 1:43), whose history he meticulously pieced together over a decade during which he, too, symbolically constructed the Angolan nation.

Maintaining a sympathetic and yet critical perspective on the pamphletarian, populist tendencies advocated by some members of the Union of Angolan Writers towards 1979, Hamilton warns about the dangers of cultural relativism; his scholarly support is the work of Brazilian anthropologist Darcy Ribeiro. With the ample democratic vision cultivated throughout his career, he defends the need to build the new Angolan literature on the legacies of the past, nonetheless recognizing that not all traditions may have a place in the developed nation of the future (Literatura Africana 2:173). This is the type of sensitive critical appreciation where the sociology of literature never loses sight of artistic and intellectual considerations that are broad and, most of the time, comparative. Herein lies what the writers of this Introduction consider one of Hamilton's greatest lessons as a teacher and critic.

Looking back at the first volume of Literatura Africana, Literatura 
Necessária from the perspective of the unjustly forgotten essay, "Lusofonia, Africa, and Matters of Languages and Letters," published in Hispania in 1991, and reprinted in Callaloo in that same year, the reader is struck by Hamilton's pioneering critical-theoretical acumen. Although his name has never figured alongside the likes of Homi Bhabha and others, he puts forward in the introduction to that volume a number of issues that clearly outline a postcolonial critical lens. Without ever evoking the term, which, around 1980, when he was writing, was still far from becoming the equivocal catchword upon which much theory evolved, Hamilton identifies and engages with not only thorny questions of definitions but, also, the historical specificities to bear in mind for a sound and enduring postcolonial approach to Lusophone African literatures.

The main frame of reference informing Hamilton's historical presentation and sociological interpretation of those literatures is the condition of socioeconomic weakness, political marginality and general lack of prestige characterizing late Portuguese colonialism, ensuing from the mandates laid out and agreed upon by the strong European powers at the Berlin Conference. Having increasingly fallen into a socio-economically weak and politically marginal position since the late sixteenth century, Portugal did not possess the resources nor human power necessary to fulfill the expectations of European colonialism. Hence, the emergence, particularly notable between the late nineteenth century and the 1950s, of a mixed-race society with hierarchies across race and class that conditioned high culture and, specifically, literature. And connected to Portugal's lack of prestige and increasing isolation as a European empire, Hamilton is keen to discuss the relatively low status of Portuguese in comparison with English and French as colonial languages. So, even though African literatures of Portuguese expression were arguably written earlier than any other, as Gerald Moser had argued in a 1969 article, they remained little more than invisible due to the lack of world recognition of Portuguese as a language, to which the critic adds an important reminder about the appalling situation of Portuguese colonialism in Africa in later years (Hamilton, Literatura Africana 1:16-7).

Before continuing, Hamilton tackles two important problems of nomenclature and definition. The first is what to call the literatures of the five newly independent African nations formerly colonized by Portugal. He is not in favor of collapsing the oral traditions of storytelling into literature, preferring to distinguish between the two. He sheds light on the implications of neo-colonial 
dependency potentially implied by the common descriptors used to refer to African literatures written or "expressed" in a European language, wisely pointing out that African literature, whether in the continent or anywhere it may be found in the African diaspora, inevitably carries the memory of what makes it unique as such - the historical facts of slavery, oppression, and prejudice. To keep both the African specificity and the memory of colonialism without, nonetheless, implying more dependency than what the European language in which literature is written makes inevitable, Hamilton opts for the phrase, "Literature of Lusophone Africa" (Literatura Africana 1:21).

The second area involving the need for clarification of terminology pertains to the ambiguous status of colonial culture and its language as appropriated by the native subject. After exposing the violence of the process of acculturation for the colonial subject, who becomes thereby deprived of her/his African roots or, at the very least, cultural practices, Hamilton recuperates whatever negative, racist implications the term "creole" came to have in the Lusophone colonial (and neo-colonial) context. He considers the creole subject as the positive example of how the native can counteract colonial violence, creating an original, autonomous language out of the contingencies of acculturation and while refusing to be bound to the standard of correct language use imposed by the colonial metropolis (Literatura Africana 1:22-23). This discussion sets the stage for and prepares the discussion of five main points to bear in mind when approaching that language or, better, the different languages of the five national Lusophone African literatures.

Closely following Chinua Achebe's discussion of what constitutes a national African literature (as per the now famous essay, "English and the African Writer," published in 1965), Hamilton answers affirmatively the thorny question of whether it is possible to have an African literature written in the language of the colonizer, in this case, Portuguese. After all, he notes, there are already plenty of African literatures written in English, French, and Portuguese. ${ }^{2}$ The issue is not writing in a language considered "national," rather than "ethnic," as the case would be if the literatures in question were written in the many different African languages. The issue is, rather, how those literatures achieve

\footnotetext{
${ }^{2}$ It is interesting to note the omission of any reference to African literatures written in Spanish, which at the time had not yet been "discovered" by academics.
} 
authenticity, something related to how that national language is used and the several historical, social, political and cultural factors conditioning that use (Literatura Africana 1:26-9).

Despite lacking prestige and international recognition, Portuguese became nonetheless the language that united all five countries against the colonizer; and it is Portuguese that continues to be - according to the critic writing in 1979-80 - the language in which those countries "communicate with the world" (Literatura Africana 1:26). Hamilton evokes Amílcar Cabral's reported assertion regarding the only positive legacy of the colonizer, connecting it to Shakespeare's famous example of Caliban expropriating the language that the master, Prospero, had taught him (Literatura Africana 1:26). ${ }^{3}$ The ideal of achieving authenticity writing in the language of the colonizer is connected to linguistic recreation and innovation-something the critic considers Angolan literature was doing particularly well at the time (Literatura Africana 1:29). Hamilton's close, sensitive attention to such innovation is demonstrated later on in the volume, in his discussion of experiments in artistic language in works published by José Luandino Vieira, Uanhenga Xitu and Pepetela during the independence period (Literatura Africana 1:214-29).

The identity of race and class that it is assumed to surface in works written by Africans is the third critical problem engaged by the critic. He considers the different meanings that such an attribution may or may not have, denying that they can be predetermined or defined extrinsically on the basis of the writer's racial identity. Hamilton problematizes in particular the concept of "Black literature." He highlights the racism and separatism implied in such a category arguing that the ways in which black subjects and African cultures are portrayed, and from the perspective of whom, matters more than the actual race of the writer. Cases of "black literature" from the United States, Cuba, and Brazil are brought up to shed light on the commonality of experiences regarding slavery, oppression and poverty that mobilized Africans and African descendants to write "black literature" as a gesture of political challenge and nationalist cultural revindication

\footnotetext{
${ }^{3}$ The use of the Prospero/Caliban metaphor by African and Caribbean anti-colonial writers has a history with which Hamilton was surely familiar. Roberto Fernández Retamar's "Caliban: Apuntes sobre la cultura in nuestra América" (1971) was widely known by 1980, and the first two volumes of the anthology by Manuel Ferreira, No Reino de Caliban: Antologia panorâmica da poesia Africana de expressão portuguesa, were published in Lisbon in 1975 and 1976.
} 
(Literatura Africana 1:31-3). However, Hamilton points out that Mário Pinto de Andrade's most recent anthology, published in two volumes in 1976 and 1979, is titled Antologia Temática da Poesia Africana, thus omitting any reference to "race" (Literatura Africana 1:34). Observing that the "racial composition" of the literary-cultural intelligentsia of the new independent countries differs markedly from that of the Anglophone and Francophone African counterparts, Hamilton connects the multiracialism of Lusophone African writers to the economic conditions of Portuguese colonialism as well as to the social structures that it encouraged. Since the colonies had been abandoned by the metropolis for so long, the small number of Europeans who did migrate to the African colonies frequently underwent a process of "Africanization," taking on local women as their companions and mothers of children. A hierarchical social-racial structure was created in this context, particularly exacerbated by the difference between "civilized" or "assimilated" and "non-civilized" or "indigenous" Africans (Literatura Africana 1:34-5). Changes in the socio-economic structures brought about by independence society will inevitably alter the racial predominance of white and mestiços among the authors of Angolan literature. What matters the most for Lusophone African literatures, from Hamilton's perspective at the time of writing, does not center on any one race or relations of race but on the representation of "the racial, social and ethnic problems inherited from the colonial past" (Literatura Africana 1:37).

The parallel and at times ambiguously crossed histories of Negritude and Lusotropicalism constitute the fourth and arguably most enlightening frame of critical-theoretical reference identified in the volume's Introduction. Hamilton demonstrates how crucial they are to the understanding of Lusophone African literatures; and specifically how Negritude, having arrived in the Lusophone space around 1964 when it was no longer combative, was ideologically malleable (Literatura Africana 1:40). Examples as notably different as Alfredo Margarido, affiliated with Casa dos Estudantes do Império, who published in 1964 the booklength essay, Negritude e Humanismo; and the essays composing Portugueses e Negritude (1970), by the Portuguese writer, journalist and (reputedly) supporter of the regime, Maria da Graça Freire, are cited as examples of the opposite uses to which Negritude was put at the time. Maria Carrilho's excellent book, Sociologia da Negritude (1976) is Hamilton's main support in pointing to the conservative ends that Negritude served when used to disavow a colonialism that 
had long survived all other European colonialisms on the African continent. And he warns repeatedly against the generalized use of the term by critics who ignore its history (Literatura Africana 1:42-3).

Hamilton's signature critical/theoretical concept, "acculturated literature," closes the Introduction to Literatura Africana, Literatura Necessária. It constitutes the fifth frame or lens through which he invites the reading of Lusophone African literatures; and it consists of a thoughtful consideration of their main artistic, intellectual and ideological sources. Here, too, he evokes Chinua Achebe's distinction between literature written "in" Africa and literature "of" Africa to point out that, despite their commonly acculturated status, a more legitimate or authentic direction is found in that literature that subverts or uses for its own ends the European traditions from which it draws (Literatura Africana 1:43-4). Even though it is not meant to discourage comparisons with Francophone and Anglophone African literatures, it is important to note our critic's observation that Lusophone African literatures owe much more to European, Cuban, and American literary currents than to African literatures written in European languages. Portuguese neorealism, itself influenced by Brazilian regionalism, figures as an important ideological and artistic source; writers such as Agostinho Neto, Mário Pinto de Andrade, Amílcar Cabral and Marcelino dos Santos were involved in clandestine anti-colonial struggle along with neo-realists. But it is the language, the human and ecological scenes typical of the northeastern Brazilian novel that were suggestive of the conditions lived by Africans under Portuguese colonialism (Literatura Africana 1:45). In addition, and not surprisingly, Hamilton points out that the Cuban poet, Nicolás Guillén and the African-American poet, Langston Hughes, were both notable inspirations to Lusophone African writers' attempts at consciousness-raising and cultural and political empowerment through literature (Literatura Africana 1:446). As they seek to engage new post-independence realities through new contents and forms, the literatures produced in the few years after independence carry forth the memory of the works that, in the past, prepared the way for the process of national construction. For this reason, the critic notes, it is necessary to know that literary past whose legacy is inevitably carried by present and future writings in Lusophone Africa (Literatura Africana 1:46).

Hamilton's appeal for the need to know and contributions toward the histories of the "acculturated literatures" of Lusophone Africa did not find much 
echo until about the 2000s. ${ }^{4}$ Attention to colonial literatures and cultures has increased in the last few years, however, and with it a more rounded, less Manichean and finer understanding of the contribution of colonial writers to the respective national literatures and to Lusophone African literatures more generally. Cases in point are the articles by Rita Chaves on the Angolan writer, Óscar Ribas, and by Inocência Mata on the Cape Verdean poet, Jorge Barbosa, included in this issue.

In the second volume of Literatura Africana, Literatura Necessária, dedicated to Mozambique, Cape Verde, Guinea-Bissau, and São Tomé e Principe, Hamilton offers important observations regarding the birth of BissauGuinean literature written in Portuguese and Kriol. He highlights the late emergence of a written literature in Guinea-Bissau, in contrast to the other former Portuguese African colonies, due to sheer neglect on the part of the colonial regime with regard to Portuguese Guinea. The neglectful attitude is underscored by the dismal literacy rate in the colony and the fact that the first high school in Bissau was created only in 1949. This disadvantage contributed to an interesting scenario in the case of Guinea-Bissau, whereby its national literature skipped the cultural resistance phase, or "fase reivindicatória" (Literatura Africana 2:218) that characterized the other literatures, and instead it emerged in the midst of the anti-colonial struggle and the birth of the nation. Thus, Hamilton argues that historical agency and literary production became "inseparáveis da dimensão sociopolítica de uma sociedade emergente" (Literatura Africana 2:218).

Two pioneering literary anthologies were published immediately after independence: Mantenhas para quem luta! (1977) and Antologia de jovens poetas (1978), which included among others, key figures such as José Carlos Schwartz e Helder Proença. According to Hamilton, these anthologies constitute the basis of a literature "num país praticamente sem a tradição de uma escrita literária autóctone" (Literatura Africana 2:221). In both cases, the poetic act became the equivalent of the political act. Despite writing with a sense of urgency and a heightened awareness of being among the first writers within a nascent literary tradition, the writers included in both anthologies are "sensíveis à forma

\footnotetext{
${ }^{4}$ Francisco Noa's PhD dissertation, defended at the Universidade Nova of Lisbon in 2001 and published in book form by Editorial Caminho, in Lisbon, in 2003, with the title, Império, Mito e Miopia-Moçambique como invenção literária, is usually cited as an example of this new attention to colonial literature.
} 
em que a mensagem é transmitida" (Literatura Africana 2:221), therefore, they did not consider literary art simply as a means for political propaganda. Beyond these anthologies, Hamilton calls attention to the poetry written by the brothers Vasco e Amílcar Cabral during their time in Portugal as college students where they frequented the Casa dos Estudantes do Império. (Vasco Cabral's poetry remained unpublished until 1979).

Writers in Guinea-Bissau strove to balance the need for asserting the existence of the nation in political, as well as in ethnic and cultural terms vis-àvis the larger Portuguese-speaking world. At the same time, they addressed the diverse peoples of Guinea-Bissau, at a time when Kriol was consolidating itself as the language of the armed struggle, the nations's lingua franca, and mother tongue, as pointed out by Mário Pinto de Andrade in his essay "A estrutura das línguas africanas vai domesticar a língua portuguesa" (1977), cited by Hamilton (Literatura Africana 2:225).

The written literature of São Tomé e Príncipe, on the other hand, emerged rather early in a highly stratified society among the mixed race elite (or "filhos da terra"), rooted in a history of economic cycles of sugarcane, cocoa, and coffee, where slave labor as well as indentured labor ("trabalho contratado") played a key role. In this context, the plantation farm (or "roça") became the privileged social and symbolic site of representation. Hamilton argues that San Tomean literature in Portuguese actually started in the metropole during the late nineteenth century through the work of Caetano da Costa Alegre (1864-90), a son of the mixed race elite who studied in Lisbon. The primarily rural economy of the islands precluded the emergence of urban centers such as Mindelo, Luanda, or Lourenço Marques, where there were high schools, thus forcing the San Tomean elite to study in Portugal. Hence, the founding figure of San Tomean poetry was a black African man in late nineteenth-century Lisbon. Inevitably, his poetic discourse - historically unique - became laden with political and racial commentary that was defiant, transgressive, and at times, humorous, as in his poem "Eu e os passeantes." Another pioneering figure of San Tomean letters, Francisco José Tenreiro (1921-63), played a unique role as intellectual, geography professor, writer, and politician, occupying a liminal space between Portugal and Africa. In Voices from an Empire, Hamilton states that Tenreiro "embodies both the awareness and the ambivalence of a black, white, and mestiço elite whose collective voice has resounded from an empire in demise" (388). 
Tenreiro in fact became one of the earliest major Lusophone African writers to embrace the lessons of Francophone Négritude, Anglophone Panafricanism, the Harlem Renaissance, as well as Cuban negrismo, while forging an AfroPortuguese or Afro-Lusophone Negritude imbued with a strong mixed race consciousness that Hamilton labels as mulatitude (Literatura Africana 2:252), which manifests itself in poems such as "Corpo moreno" and "Canção do mestiço."

Other key San Tomean poets that are representative of the transition between cultural resistance and political militancy, according to Hamilton, include Tomás Medeiros, Maria Manuela Margarido, and Alda do Espírito Santo (the latter is considered one of the founding mothers of Lusophone African literature). In Dona Alda's case (as she was known in São Tomé), the poem "Onde estão os homens caçados neste vento de loucura" stands out for its urgency in lamenting and denouncing the infamous Batepá massacre that took place in 1953. By the same token, her poetic work is known for its nativism that celebrates the culture of São Tomé, as well as its land and its people, while emphasizing the role of women. In the preface to her anthology, É nosso o solo sagrado da terra (1978), Alda do Espírito Santo, according to Hamilton, articulates a consciousness that is simultaneously feminist and anti-colonial as she claims a central place for women in the liberation struggle: "a mulher africana duplamente colonizada, escrava doméstica, serva da colonização, tem a missão secular a desempenhar na etapa da libertação" (qtd. in Hamilton, Literatura Africana 2:259).

The case of Cape Verdean literature must be understood in the context of a majority mixed-race society that enjoyed a special status in the history of the Portuguese African empire, where the first high school was opened in the capital city of Praia in 1860 and the first seminary was created on the island of São Nicolau in 1866. The Cape Verdean lettered elite that emerged from this context forged a complex cultural and geopolitical relationship with Africa, Portugal, and Brazil at the crossroads of the Atlantic. Hamilton points out that Cape Verdean intellectuals saw themselves as "actors" within the colonial power structure and not mere subordinate subjects (Literatura Africana 2:95). He also suggests that early Cape Verdean intellectuals, mostly Mindelo-based, tended to be Eurocentric and rather disdainful of Africa (Literatura Africana 2:98-99). Meanwhile, the thematic spectrum of early Cape Verdean literature was shaped by the archipelago's history, geography, climate - and most particularly - the 
intrinsically diasporized condition of the Cape Verdean nation. This is due to the forced migration of slaves from the West African coast to the islands, economic migration from the islands to various parts of the world (including New England), and indentured labor migration to São Tomé e Principe- the latter two phenomena in connection with severe cyclical droughts, famine, epidemics, and unemployment. From a linguistic standpoint, Cape Verde is an example of a diglossic nation with a deep-rooted oral culture that expresses itself in multiple variants of Cape Verdean Kriolu and a written culture that exists primarily in Portuguese. As with the case of Guinea-Bissau, Hamilton was attentive to this complex linguistic scenario and the tensions arising as a result of it in the context of literary production.

Journals were central to the history of Cape Verdean literature, and Claridade became the cornerstone of the literary field on the West African archipelago. The journal lasted thirty years, between 1936-66, and only nine volumes were published. Even though it went through various phases and did not necessarily offer a monolithic view of Cape Verdean culture, Claridade provided a platform through which to disseminate knowledge regarding a nation that was distinct from Portugal. Hence Cape Verde's constitutive Creole identity became an object of investigation and celebration through short stories, poetry written in Portuguese and in Kriolu, ethnographic accounts, linguistic studies, and oral folklore. The founding figures were Manuel Lopes, Baltasar Lopes, and Jorge Barbosa. Other major contributors included Félix Monteiro, Gabriel Mariano, and Teixeira de Sousa. Hamilton highlights the intellectual as well as culturalliterary affinities between Claridade and the avant-garde movements of Portugal and Brazil. In the latter case, São Paulo-based Modernismo and the Northeastern regionalistas centered around Pernambuco played a major role in inspiring a regional consciousness among Cape Verdeans. The fact that the archipelago was under colonial rule provided a sense of urgency in claiming a distinct protonational identity (122). Another journal, Certeza, of which only two volumes were published during a hiatus period of Claridade (1938-47), was more influenced by Portuguese neorealism and Brazilian social realism. While championing high literature written in Portuguese as opposed to oral traditions or Kriolu, according to Hamilton, the tone of Certeza was more rebellious vis-àvis Portuguese colonial power, a fact that led to its eventual censorship. 
The nativism that marked early Cape Verdean literature revealed an existential dualism between land/sea, drought/rain, staying/leaving, insularity/cosmopolitanism, and Europe/Africa, as expressed by Hamilton (Literatura Africana 2:124). In fact, Francisco José Tenreiro and Mário Pinto de Andrade excluded Cape Verde from the Caderno de Poesia Negra de Expressão Portuguesa (1953) since it did not "traduz o sentimento de negritude" (132). The Claridade movement in Cape Verde was an exception among African intellectual and cultural movements in that it claimed not an African identity for Cape Verde, but a Creole identity, which in the early years of the movement emphasized the country's European roots. Several writers eventually distanced themselves from the Eurocentric inclinations of the early claridosos (the nickname given to members of Claridade), thus emphasizing the Africanness of Cape Verdean culture: Manuel Duarte, Gabriel Mariano, and Onésimo Silveira.

In the case of Mozambique, there were few signs of a proto-national literature until the 1940s, according to Hamilton (Literatura Africana 2:14). The early literary field in Mozambique was also shaped by the complex and divisive racial politics of Portuguese colonial society. As the critic argues, Lourenço Marques, in contrast to Luanda, did not possess a cohesive cross-racial intellectual elite (Literatura Africana 2:12). The three distinctive racial groups (white, black, and mixed-race) were deeply divided among each other. Only the rise of Mozambican nationalism later on was able to bring the various groups together, especially blacks and mixed-race (Literatura Africana 2:12). While urban cultural life amongst the various elite groups revolved around social clubs or associations, literary production was disseminated through a variety of journals that would play a key role in the rise of Mozambican lettered culture (primarily in Portuguese) and nationalism, for example, the long-lasting and venerable $A$ voz de Moçambique and $O$ brado africano.

Hamilton refers to the efforts by Portuguese critic Manuel Ferreira and Mozambican prose writer Luís Bernardo Honwana in delineating the contours of a nascent modern Mozambican literature, especially in the realm of poetry. In this context, several figures stand out, such as Noémia de Sousa, Rui Nogar, José Craveirinha, and Malangatana (better known as one of Africa's greatest painters)-all of them united in their pursuit of an emancipatory African literature in Mozambique. Noémia de Sousa, together with San Tomean poet Alda do Espírito Santo, are founding mothers of African literature written in 
Portuguese. Hamilton describes Noémia as the first female writer "of color" in southern Africa (Literatura Africana 2:36). The sense of racial and cultural empowerment embedded in her poetry are Noémia's most important contribution to the history of Mozambican literature, according to the critic (34) - an honor that she fully shared with the towering figure of Mozambican letters, José Craveirinha. Hamilton suggests that one of the main differences between the two poets, beyond the sheer volume of Craveirinha's work, is the fact that he succeeded in "Africanizing" his poetic language to the point of becoming "the foremost interpreter of Mozambicanness" (Voices from an Empire 202), an insight he shares with Gerald Moser. Further, Hamilton extols above all the aesthetic-ideological strength of Craveirinha's poetic discourse. In the realm of prose fiction, on the other hand, the critic highlights Honwana's Nós matamos o cão tinhoso (1964) as the paradigmatic Mozambican literary work that also became the first Lusophone African fictional collection to be included in translation as part of the largely disseminated English language "African Writers Series." Hamilton considers the political and cultural import as well as the literary originality (at both the aesthetic and linguistic levels) in Honwana and Craveirinha as veritable "revolutionary acts." (Literatura Africana 2:46).

Hamilton divides the development of Mozambican literature into three distinct phases: 1) an initial phase of acculturated literature produced by members of an indigenous and multiracial bourgeoisie who considered themselves Mozambicans and not subjects of the Portuguese empire; 2) a second phase that involved a cultural and racial emancipatory dimension, coupled by reformist protest; and 3) a social protest phase that became militant and combative in the heat of the liberation struggle (Literatura Africana 2:50). During the final preindependence phase, the figure of Marcelino dos Santos stands out as a poet who cultivated a didactic and moralistic language during a prolific career since his time at the Casa dos Estudantes do Império in Lisbon. In his seminal work, Lutar por Moçambique (1969), Eduardo Mondlane calls for a literature to be put at the service of the FRELIMO liberation movement. Hamilton argues, however, that literature in this context went beyond its use as mere political propaganda to fulfill a role in expanding literacy as well as creating a sense of nationhood (Literatura Africana 2:54).

As a critic of African literatures in Portuguese based in the United States, Hamilton was not alone. He was much indebted to Gerald Moser, who published 
the pioneering book length study, Essays in Portuguese-African Literature (1969) and taught at Penn State University for many years. Donald Burness, for his part, published several important collections of essays and anthologies, including Fire: Six Writers from Angola, Mozambique, and Cape Verde (1977) and A Horse of White Clouds: Poems from Lusophone Africa (1989), prefaced by Chinua Achebe. Burness is also founding member of the African Literature Association.

As the literary and cultural production of the five Lusophone African nations has expanded over the years, so has the academic field since the pioneering days of Moser, Hamilton, Burness, Ferreira, Maria Aparecida Santilli, Benjamim Abdala Jr., Laura Padilha, and Simone Caputo Gomes (in the US, Portugal, and Brazil respectively) between the 1960s and 80s. In Brazil, the field has experienced a veritable explosion since the study of Africa and Afro-Brazilian history and cultures was made a requirement at the pre-college level during the Lula administration in 2003. Meanwhile, as the field of Portuguese continues to expand gradually in US higher education, so has the inclusion of Lusophone Africa as an object of study. The continued vitality and growth of Lusophone African studies will also depend on the openness towards multi- and interdisciplinarity and the establishment of strategic alliances with colleagues in the humanities, social sciences, and the arts, who focus on Lusophone African nations, on other African regions and linguistic blocs, on the south Atlantic, or on the African Diasporas in Europe and in the Americas.

\section{$* * *$}

Our tribute includes a selection of personal and academic testimonies of Hamilton 's contribution to the academic profession, to the field of Portuguese at large and, specifically to the emergence of studies and criticism on Lusophone African literatures. In addition, it features scholarly essays on colonial and postcolonial Lusophone African literatures, on Lusophone literary and cultural communities in the age of globalization, as well as on the process of systematization of the African literary field.

After the introduction, the opening section begins with historian Allen Isaacman's memories of Hamilton as a pioneering colleague in African Studies 
at the University of Minnesota. What follows is a deeply moving text by beloved Mozambican writer Luís Bernardo Honwana, who remembers Hamilton as a friend and comrade in the field of literary studies. David Brookshaw then highlights the seminal contribution of Voices of an Empire and the rise of Lusophone African literary studies in the United Kingdom. And Nazareth Soares Fonseca follows suit, outlining the contribution of Literatura Africana, Literatura Necessária to the formation of a program of study in Lusophone African Literatures at the Catholic University of Minas Gerais, in Belo Horizonte, Brazil.

Inocencia Mata explores the representation of women in the work of the foremost Cape Verdean poet of the pre-independence era, Jorge Barbosa, at a time when gender concerns were subsumed under nationalistic imperatives. Rita Chaves analyzes the groundbreaking novel Uanga (1951) by Angolan novelist, poet, ethnographer, and linguist, Óscar Ribas, whom she argues, writes from the interstices of a deeply divided late colonial society. Eleanor Jones investigates the uses of a "pathologized body" as framing devices for the internal enemy in the speeches of Mozambican president Samora Machel during the early nationbuilding period. Niyi Afolabi examines the dynamics of transculturation in contemporary novels from Angola, Cape Verde, and Mozambique by José Eduardo Agualusa, Germano Almeida, and Mia Couto, respectively. Benjamim Abdala Júnior discusses geopolitical questions in connection to the processes of globalization by way of what he terms 'cultural communitarianism' among Portuguese-speaking nations. Finally, Luís Kandjimbo offers a meta-theoretical reflection on comparative African literary studies in the process of systematizing the field as a whole.

\section{Works Cited}

Andrade, Mário Pinto de. "A estrutura das línguas africanas vai domesticar a língua portuguesa." Diário de Lisboa, 30 June 1977:10-11. Print.

Burness, Donald. A Horse of White Clouds: Poems from Lusophone Africa. Athens, OH: Ohio U, 1989. Print.

-. Fire: Six Writers from Angola, Mozambique, and Cape Verde. Washington, DC: Three Continents, 1977. Print.

Carrilho, Maria. Sociologia da negritude. Lisbon: Edições 70, 1976. Print. 
Espírito Santo, Alda. É nosso o solo sagrado da terra. Lisbon: Ulmeiro, 1978. Print.

Fernández Retamar, Roberto. Calibán: apuntes sobre la cultura en nuestra América. Mexico City: Diógenes, 1971. Print.

Ferreira, Manuel, ed. No reino de Caliban: antologia panorâmica da poesia africana de expressão portuguesa. 2 vols. Lisboa: Seara Nova, 1975-76. Print.

Freire, Maria da Graça. Portugueses e negritude. Lisbon: Agência-Geral do Ultramar, 1971. Print.

Hamilton, Russell. Literatura africana: literatura necessária. 2 vols. Lisboa: Edições 70, 1981-84.

- Voices from an Empire: A History of Afro-Portuguese Literature. Minneapolis: U of Minnesota P, 1975. Print.

Honwana, Luís Bernardo. Nós matámos o cão-tinhoso. Lourenço Marques: Sociedade de Imprensa de Moçambique, 1964. Print.

Margarido, Alfredo. Negritude e Humanismo. Lisbon: Casa dos Estudantes do Império, 1964. Print.

Mondlane, Eduardo. Lutar por Moçambique. Lisbon: Sá da Costa, 1975. Print.

Moser, Gerald M. Essays in Portuguese-African Literature. University Park, PA: Pennsylvania State UP, 1969. Print.

Noa, Francisco. Império, Mito e Miopia-Moçambique como invenção literária. Lisbon: Caminho, 2003. Print.

Ribas, Oscar. Uanga, feitiço. Luanda: Lello, 1951. Print.

Tenreiro, Francisco, and Mario Pinto de Andrade, eds. Poesia negra de expressão portuguesa. Lisboa: Editora Gráfica Portuguesa, 1953. Print. 